\title{
ON FIBRES, PARENCHYMA AND \\ INTERMEDIATE FORMS IN THE GENUS MICONIA (MELASTOMATACEAE)
}

\author{
B. J. H. TER WELLE and J. KOEK-NOORMAN
}

Instituut voor Systematische Plantkunde, Rijksuniversiteit Utrecht

\section{SUMMARY}

A preliminary account is given of the parenchyma-like tangential bands, as seen on the transverse surface of Miconia species. The bands consist of parenchyma strands, fusiform parenchyma cells and fibres. These fibres differ from the fibres of the ground tissue in wall thickness, lumen diameter and sometimes in pit size. In the bands intermediate forms between parenchyma cells and fibres occur.

The functional relationship between the elements forming the parenchyma-like bands is discussed.

The systematic value of this phenomenon is still uncertain. In other genera of the Melastomataceae, however, as well as in other families of the Myrtales it has also been observed.

\section{INTRODUCTION}

In the course of an anatomical investigation into the structure of the wood of neotropical Melastomataceae it appeared that species of the genus Miconia show an unusual diversity in the morphology and distribution of fibres and parenchyma strands. Wood of Miconia species is, generally, characterized (on inspection with a hand lens) by a banded appearance of the transverse section. These rather vague bands are more or less regular and concentric and of a lighter colour than the fibre tissue. While studying a large number of representatives of Miconia we were struck by the great variation in the nature of these bands. Sometimes they stood out so clearly that the banded pattern of the cross section was visible to the naked eye, in other species bands were hardly visible. Microscopical investigation of the bands showed a considerable variation in their composition, both fibres and parenchyma being present in various quantities and the fibres in particular were of two different morphological types. As this phenomenon is not restricted to the genus Miconia, but was also noticed in other genera of Melastomataceae and even in other families of the Myrtales (personal communication of dr. P. Baas and Messrs. G. J. C. M. van Vliet and R. C. V. J. Zweypfenning, Rijksherbarium, Leiden), it seemed of sufficient interest to give a brief preliminary account of the most frequently occurring types of band-forming elements in Miconia. 


\section{METHODS}

For this paper, we selected among our material of Miconia six species representing three different types of bands. One, $M$. guianensis, is a representative of the species showing very pronounced bands. M. eriocalyx is an example of the group in which bands are hardly visible and $M$. dodecandra represents the largest group, characterized by rather vague, but well-visible bands. Descriptions and illustrations are given to demonstrate the nature of the bands and the morphology of the elements present in the bands.

Blocks were cut with a sledge microtome and the sections were stained with saffranin. Length measurements were made of macerated material. Besides, these macerations were used to study the morphology of the elements.

\section{MATERIAL}

M. dodecandra (Desv.) Cogn. - Uw 2538 (Surinam, Tafelberg, Maguire et al. 24457, tree $10 \mathrm{~m}$ ); M. eriocalyx Cogn. - Uw 7768 (Brazil, basin Rio Madeira, Amazonas, Krukoff 6498); M. guianensis (Aubl.) Cogn. - Uw 1710 (Surinam, Nassau Mts., Lanjouw \& Lindeman 2346, tree 15 m); M. lepidota DC-Uw 223 (Surinam, Zanderij I, Stahel 223, big tree); M. mucronata Naud. - Uw 339 (Surinam, Powakka, Stahel 339, big tree); M. pteropoda Benth. - Uw 1857 (Surinam, Nassau Mts., Lanjouw \& Lindeman 2616, tree $12 \mathrm{~m}$ ); Uw 7933 (Brazil, basin Rio Madeira, Amazonas, Krukoff 6796, tree $9 \mathrm{~m}$ ).

\section{DESCRIPTIONS}

\subsection{Miconia guianensis Cogn.}

Regular concentric or anastomosing bands of lighter coloured tissue, which might be considered as parenchyma, are visible on cross section (fig. 7). Inspection with a microscope (figs. 1, 4) reveals, however, that the bands of 2 to 8 cells wide are composed of parenchyma strands intermingled with fibres in a relative frequency of one to two respectively. The parenchyma strands are irregularly distributed among the fibres, some form radial rows of one cell wide and up to seven cells long, others lay isolated amongst the fibres. The parenchyma strands are one to five cells high, their length is $990(720-1424) \mu \mathrm{m}$.

The fibres in the bands differ in several respects from the fibres in the "normal" fibre ground tissue. The fibres in the mixed bands have a rounded outline as seen in transverse section, leaving marked intercellular spaces between them (fig. 4). The $2.5 \mu \mathrm{m}$ thick walls are intermediate in size between the walls of the parenchyma, which are 1 to $1.5 \mu \mathrm{m}$ thick and of the ordinary fibres which measure $5 \mu \mathrm{m}$. Gelatinous walls were not noticed in the bands, whereas the ordinary fibres often have gelatinous walls. Intercellular spaces between the fibres do not occur.

Figs. 1-6. The transverse appearance of tangential bands of parenchyma and fibres in Miconia guianensis $(1,4)$, Miconia dodecandra $(2,5)$ and Miconia eriocalyx $(3,6)$.

Magnification figs. 1, 2, 3: $\times 40 ;$ fig. 4: $\times 400 ;$ fig. $5: \times 100 ;$ fig. $6: \times 250$. 
FIBRES, PARENCHYMA AND INTERMEDIATE FORMS IN MICONIA
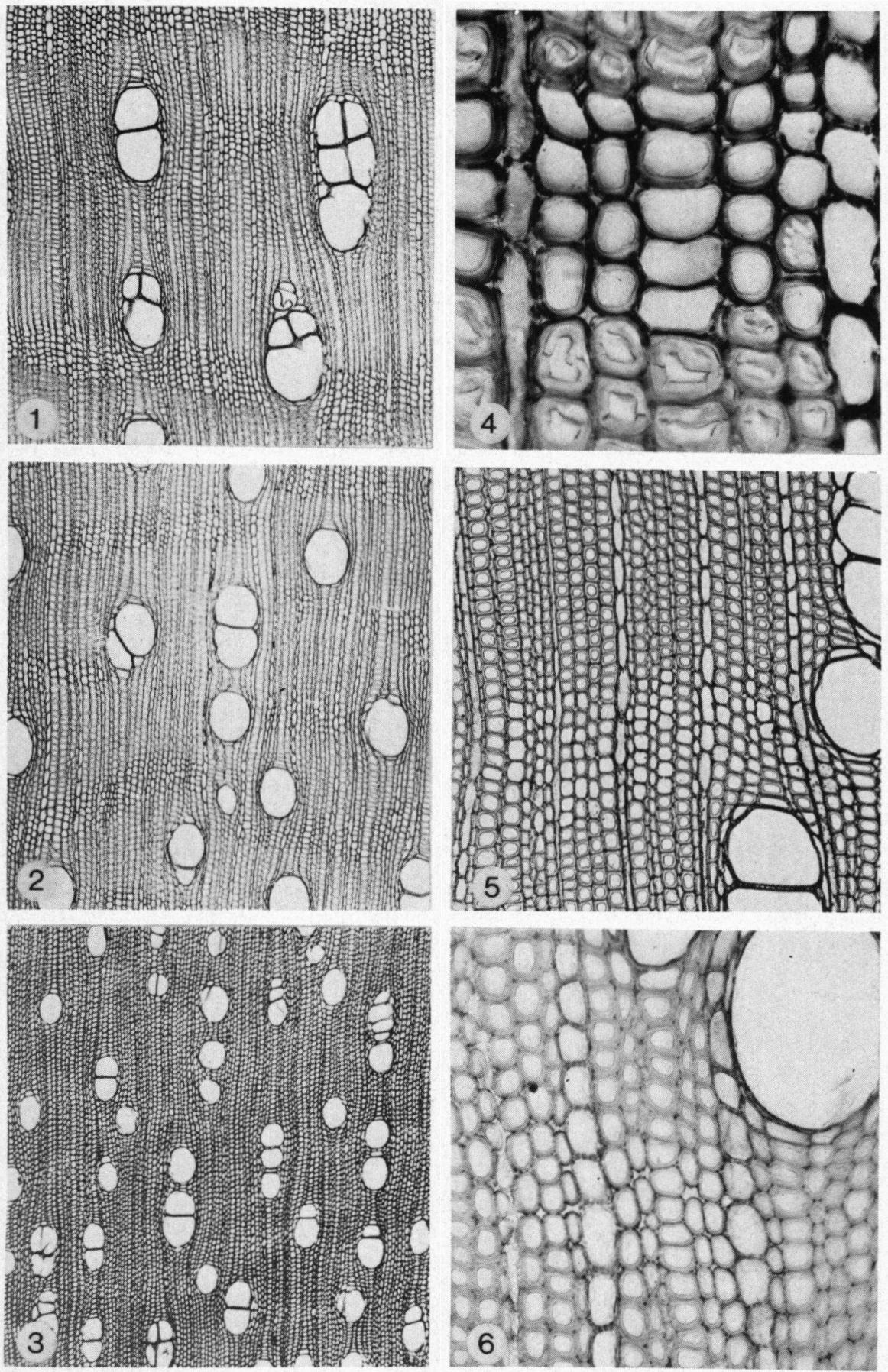

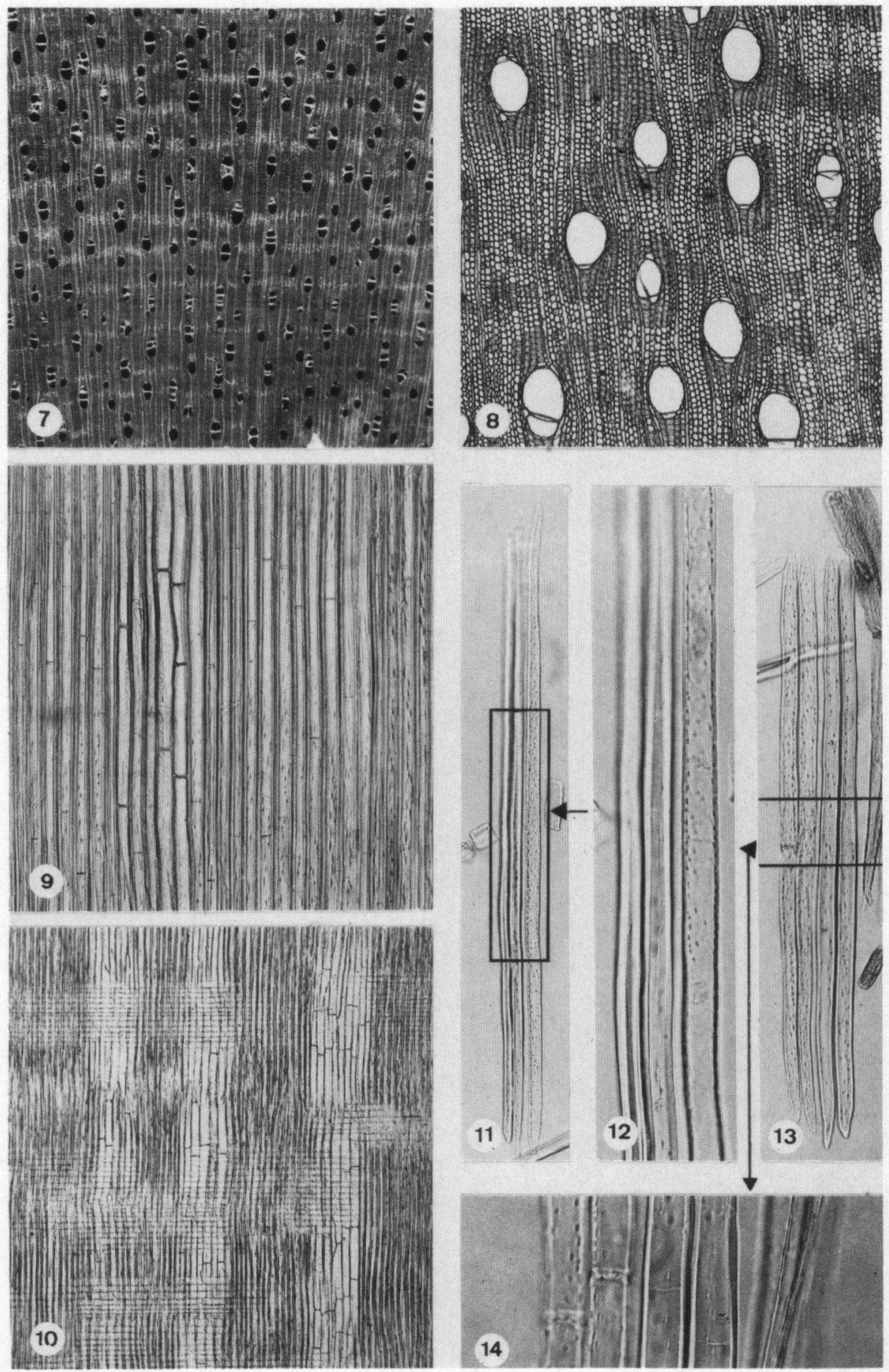
In other respect the two types of fibres are identical, both are almost always septate (1-3 septa per fibre), the pitting is the same and so is the refraction of the wall as seen in polarized light. The length is not significantly different. The length of the fibres in the bands is $1090(770-1400) \mu \mathrm{m}$ and of the ordinary fibres $1100(880-1360) \mu \mathrm{m}$.

Another species which belongs in this group is $M$. mucronata Naud.

\subsection{Miconia dodecandra (Desv.) Cogn.}

In $M$. dodecandra (fig. 2) the bands have the same distribution and size as in $M$. guianensis (fig. 1). They are composed of fibres and parenchyma in the same ratio of $2: 1$.

On inspection with a hand lens the appearance of the transverse section is somewhat different, however, the bands being less pronounced. This is due to a smaller difference in thickness between the cell walls of the fibres in the lighter coloured bands and that of the other fibres. They are $2.5 \mu \mathrm{m}$ and $3.5 \mu \mathrm{m}$ respectively. That the bands are nevertheless recognizable, is due to the wider radial dimensions of the fibre and parenchyma lumen and the presence of the intercellular spaces (fig. 5) as compared to the ground tissue. Both types of fibres are almost always septate with one or two septa per fibre. In macerations the two types are well recognizable, though intermediate forms occur as well. In one type, restricted to the ordinary ground tissue, the fibres have a small lumen, with walls about $3.5 \mu \mathrm{m}$ thick, with scarce bordered pits with a border of less than $2.5 \mu \mathrm{m}$. The other type, in the bands, is constituted by fibres with a wider lumen, with walls about $2.5 \mu \mathrm{m}$ thick, which possess numerous bordered pits with a border of $5 \mu \mathrm{m}$ wide. The length of both types is 1107 (7751375) $\mu \mathrm{m}$.

The length of the parenchyma strands is $1080(830-1465) \mu \mathrm{m}$ and they are composed of one to eight cells.

Nearly the same type of bands was found in $M$. pteropoda Benth., though variation occurred in the number and width of the bands in the two specimens investigated.

\subsection{Miconia eriocalyx Cogn.}

In $M$. eriocalyx the hand lens hardly reveals the presence of bands or any other form of a pseudoparenchyma pattern on the transverse surface. On micro-

Fig. 7. Transverse surface of Miconia guianensis photographed with incident light. $\times 8$.

Fig. 8. Transverse section of Tessmannianthus calcaratus with a pattern of true parenchyma. $\times 40$.

Figs. 9-10. Radial sections of Miconia guianensis and Tessmannianthus calcaratus. $\times 100$ and $\times 40$ respectively.

Figs. 11-12. Maceration of Miconia pteropoda showing two fibres and a septate fusiform parenchyma cell. Fig. 12 is an enlargement of the marked part of fig. $11 . \times 100$ and $\times 250$ respectively.

Figs. 13-14. Maceration of Miconia guianensis. In fig. 13 two septate fibres and two 2-celled parenchyma strands of the same length $(\times 100)$. Fig. 14 is an enlargement of the marked, crucial part of fig. $13 . \times 250$. 
scopical inspection with a low magnification a faint pattern of lighter coloured flecks can be recognized (fig. 3). A magnification of $\times 250$ (fig. 6) shows that in these flecks the fibres are thinner-walled, the lumen is wider than in the normal fibres of the ground tissue and the characteristic intercellular spaces are also present. Parenchyma strands are hardly present in the bands, but some vasicentric strands occur forming an incomplete ring around the vessels. They consist of $1-6$ cells, their length is $544(450-640) \mu \mathrm{m}$.

The fibres are almost always septate (1-3 septa per fibre), the length is 710 (430-930) $\mu \mathrm{m}$. The two types of fibres, as described for the other Miconia species are hardly recognizable in the macerations.

This rather vague type of bands is also found in M. lepidota DC. In this species the contrast between the parenchyma-like bands and the ground tissue is, however, easier to notice because the fibres in the ground tissue often have gelatinous walls and coloured contents in their lumen. In this species both fibre types are also more distinct.

\section{THE MORPHOLOGY OF THE FIBRES AND THE PARENCHYMA STRANDS}

In general fibres and parenchyma of the secondary xylem can easily be recognized as such in sections as well as in macerations. For example, a parenchyma pattern such as seen on a transverse surface in Tessmannianthus calcaratus (Melastomataceae, same tribe as Miconia, fig. 8) in a radial section shows axial bands of parenchyma (fig. 10). Miconia guianensis, therefore is unusual because though its transverse section resembles Tessmannianthus, its radial section is unlike the pattern of the former, because the axial bands here appear to be composed of parenchyma cells and fibres (figs. 1 and 9).

So far, in Miconia we noticed parenchyma strands, fusiform parenchyma cells and fibres. According to the I.A.W.A. Glossary (Committee on Nomenclature, 1964) most elements can be classified as follows:
I. parenchyma strands
- 2-8 cells high, with or without one septum per cell
II. fusiform parenchyma cells - without septa
III. fibres
- septate
- A. ordinary fibres, with 0-3 septa, con- stituting the ground tissue of the wood
B. fibres with a thinner wall and a wider lumen than those of III $\mathrm{A}$, with $0-3$ septa, accompanied by parenchyma and restricted to tangential bands with a parenchyma-like distribution pattern on the transverse surface.

A schematic drawing of these elements is represented by fig. 15 .

Sometimes, however, it is very difficult and/or impossible to classify an element. It could be a (septate) fibre or a (septate) parenchyma cell, if cell 
FIBRES, PARENCHYMA AND INTERMEDIATE FORMS IN MICONIA

fig. 15
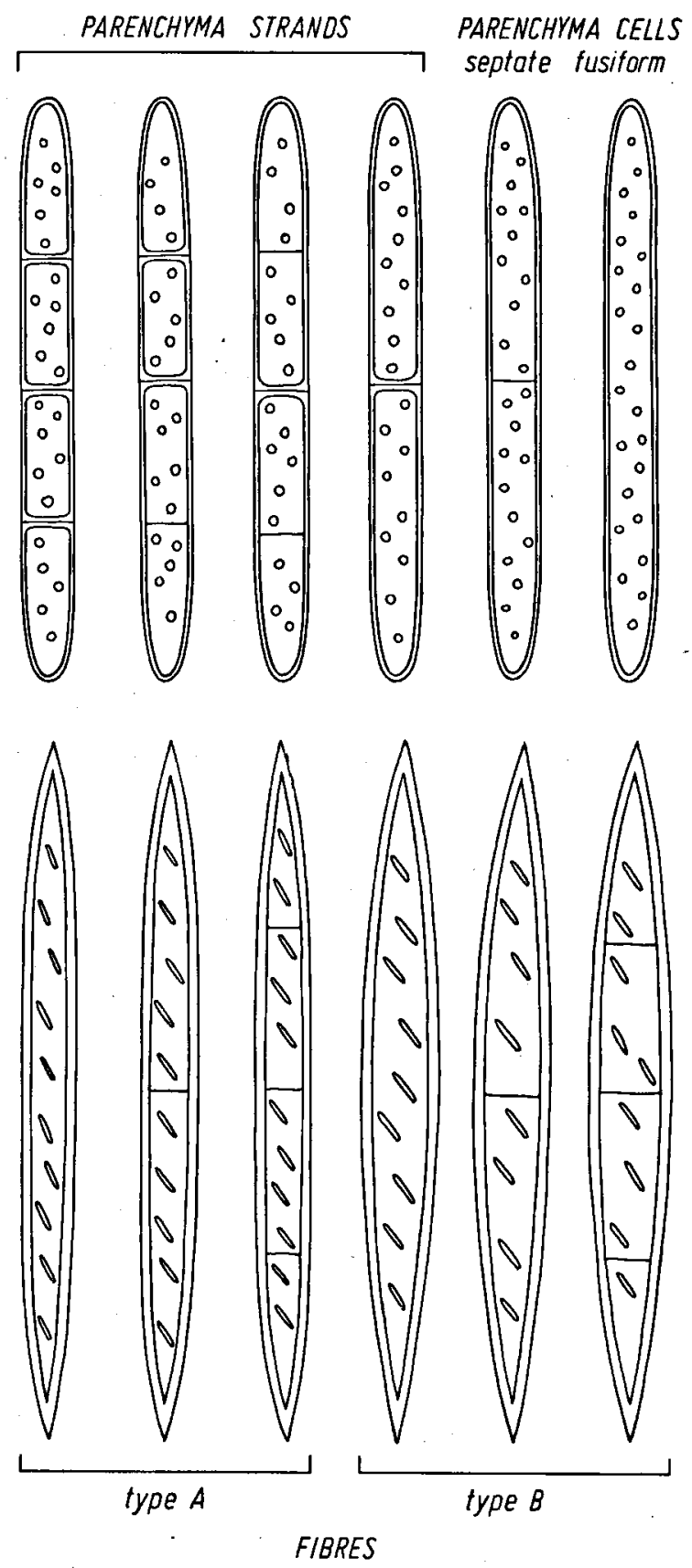
length, pitting, wall thickness and refraction of the wall in polarized light are used as characteristics. In our opinion classification of such an element as an "intermediate" form between fibres and parenchyma cells seems the best solution. Sometimes, in macerations, fibres, fusiform parenchyma cells and parenchyma strands can be found side by side. If a fusiform parenchyma cell is septate, the septum is normally found at the same level as where in adjacent 2-celled parenchyma strands the individual cells meet (figs. 11, 12, 13, 14).

\section{DISCUSSION}

Since SANIO (1863) gave his classification of the elements present in the secondary xylem, many papers on this subject have been published. Intermediate forms between vessels and fibres and between parenchyma and fibres were recognized by several authors, but each interpreted them in his own way. Because classification is usually more feasible if there are not too many classes, most authors tried to include all intermediate forms in one class or another of their own system.

However, it sometimes does not seem desirable to do so and an elaborate description of what is seen with the microscope is, in our opinion, more satisfactory. The combination of fibres and parenchyma, forming parenchyma-like bands, as seen on the transverse section of some Miconia-species was described before by JANSSONIUS (1908) who observed the same phenomenon in Elaeodendron glaucum (Celastraceae) and Dodonaea viscosa (Sapindaceae).

A description of similar bands resembling parenchyma bands, although brought about by grouping of fibres was made by other authurs (RECORD 1944; SpaCkman \& Swamy 1949; Metcalfe \& Chalk 1950; Mennega 1972). In the material seen by them the bands are always composed of septate fibres in the non-septate ground tissue. Sometimes such a parenchyma-like pattern is the result of differences in wall-thickness of the fibres as observed in Averrhoa (Oxalidaceae) by GHOSH \& PURKayastha (1960): although all the fibres are septate, the thinner-walled ones are suggestive of the presence of banded parenchyma, as seen on the transverse surface.

RECORD (1944) in his keys to American Woods, states in key XIII to woods with septate fibres: The fibers function as parenchyma strands and usually, but not always, occur where parenchyma is absent or poorly developed.

Harrar (1946) who studied a great number of species with septate fibres, noticed the frequent presence of starch grains in them and he concluded also that they function - at least in sapwood - in a manner similar to that of longitudinal parenchyma.

CARLQUIST (1958) observed in Dubautia (Compositae) bands of which: the "fibers" are shorter, wider, more frequently septate, and with much more rounded ends than fibers in other portions of the wood. These cells are tentatively termed "apotracheal parenchyma" here. The same author (1961), with reference to the same genus, stated that: thin-walled fibers may become diversified to form two types, one of them, because of their histological charac- 
teristics, must be termed parenchyma cells. Data from the literature indicate that a close functional relationship can exist between parenchyma cells and fibres. WOLKINGER (1970) and BRAUN (1970) clearly showed that living fibres may be distributed like vasicentric and terminal parenchyma (in Acer pseudoplatanus and Robinia pseudoacacia). CARLQUIST (1975) noticed a comparable arrangement in Leonia glycycarpa (Violaceae).

Our results for Miconia make it likely that such a functional relationship exists between parenchyma cells and fibres of the type, as described in the foregoing under III B. If living contents could be demonstrated in these fibres it would strenghten our hypothesis. One fresh sample of Miconia magnifica Triana (cultivated in a greenhouse) with a diameter of $c .1 \mathrm{~cm}$ and a xylem cylinder of $2 \mathrm{~mm}$ was available for examination. In the parenchyma and the fibres of both types we observed starch grains. Besides, in part of the fibres a thin film of protoplasm adhering to the cell wall was noticed. Supplementary investigations of more material are, however, needed to confirm these observations.

\section{ACKNOWLEDGEMENTS}

Sincere thanks are due to Dr. A. M. W. Mennega for her stimulating criticism in each phase of this investigation. Mr. L. Y. Th. Westra kindly corrected the english version and Messrs. A. Kuiper and T. Schipper prepared the photographs and the drawing. We gratefully acknowledge Mr. S. M. C. Topper's review of the literature on the subject of classification, definition and distribution of the elements discussed here.

\section{REFERENCES}

Braun, H. J. (1970): Funktionelle Histologie der sekundären Sprossachse. I Das Holz. In: K. Linsbauer (ed.) Handbuch der Pflanzenanatomie. Gebrüder Borntraeger, BerlinStuttgart.

CARLQUIST, S. (1958): Wood anatomy of Heliantheae (Compositae). Trop. Woods 108: 1-30.

- (1961): Comparative Plant Anatomy. Holt, Rinehart \& Winston, New York.

- (1975): Ecological Strategies of Xylem Evolution. University of California Press, Berkeley, Los Angeles, London.

COMMITTEE ON NOMENCLATURE OF THE INTERNATIONAL ASSOCIATION OF WOOD ANATOMISTS (1964): Multilingual Glossary of Terms used in Wood Anatomy. Konkordia, Winterthur.

Ghosh, S. S. \& S. K. PuRKayastha (1960): Characteristic arrangement of septate fibers in wood of Averrhoa. Sci. \& Cult. 25: 690-691.

HARRAR, E. S. (1946): Notes on starch grains in septate fiber-tracheids. Trop. Woods 85: 1-9.

JANSSONIUS, H. H. (1908): Mikrographie des Holzes der auf Java vorkommenden Baumarten. Band II. Brill, Leiden.

MenNeGA, A. M. W. (1972): A survey of the wood anatomy of the New World Hippocrateaceae. In: A. K. M. GHousE \& M. YUNUs (Eds.): Research trends in plant anatomy. Tata McGraw-Hill, Bombay-New Delhi.

Metcalfe, C. R. \& L. Chalk (1950): Anatomy of the Dicotyledons. Clarendon Press, Oxford.

ReCORD, S. J. (1944): Keys to American Woods. Trop. Woods 78: 35-45.

SANIO, C. (1863): Vergleichende Untersuchungen über die Elementarorgane des Holzkörpers. Bot. Ztg. 21 : 85-91, 93-98, 101-111, 113-118, 121-128.

Spackman, W. \& B. G. L. Swamy (1949): The nature and occurrence of septate fibres in Dicotyledons. Amer. J. Bot. 36: 804.

WolKINGER, F. (1970): Morphologie und systematische Verbreitung der lebenden Holzfasern bei Sträuchern und Bäumen. I Zur Histologie. Holzf. 24: 141-151. 